\section{WHITE ADDER'S-MOUTH AND OTHER UNUSUAL PLANTS}

BERNARD DE VRIES, Fort Qu'Appelle Herbarium, Fort Qu'Appelle, Saskatchewan. SOG 1 S0

Reading Donald Hooper's amusing account on how to lead a fisherman to water and discover a rare orchid in the process, brought to mind a similar, although less dramatic find in 1972 when the author found the delicate orchid White Adder's-mouth (Malaxis monophyllos (L.) Sw. var. brachypoda (Gray) Morris \& Eames) in a small Willow bog in Little Boggy Creek near Runnymede.' This collection precedes the earliest reference given for this orchid in Saskatchewan by two years. ${ }^{2}$ A later check of this bog turned up another unusual plant, namely the Small Primula (Primula mistassinica Michx.) a widespread but easily overlooked species.

A sharp eye for the unusual and an inquisitive mind makes for successful botanizing with the unexpected turning up, as was demonstrated during study of the Flora of Duck Mountain Provincial Park in 1982. Among the more common plants were observed, and in some instances collected, Bog Adder's Mouth (Malaxis paludosa (L.) Sw.), Butterwort (Pinguicula vulgaris L.), Thick-leaved Grape Fern (Botrichium multifidum (Gmelin) Rupr. var. multifidum) and Tall Yellow Lady's Slipper (Cypripedium calceolus L. var. pubescens (Willd.) Correll).

1 HOOPER, D. F. A new Saskatchewan record for Adder's-Mouth. Blue Jay 41(1):9-10.

2MAHER, R. V., G. W. ARGUS, V. L. HARMS and J. H. HUDSON. 1979. The Rare Vascular Plants of Saskatchewan. National Museum of Natural Sciences. Syllogeus No. 20. Ottawa, Canada.

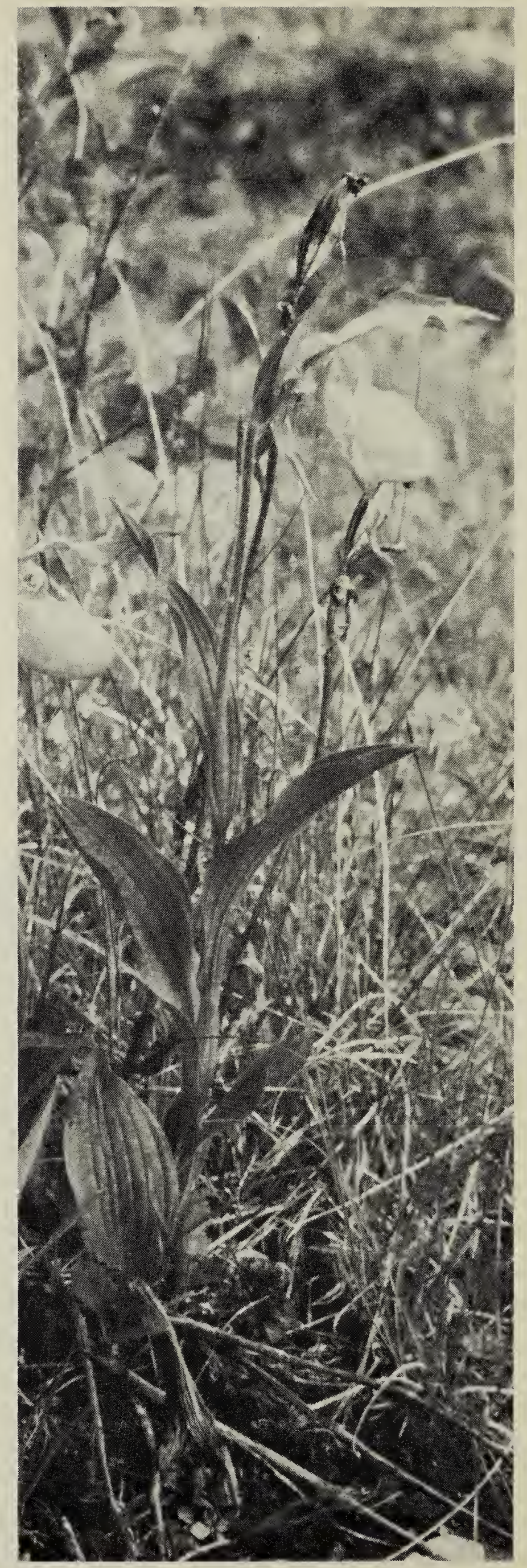

Large Yellow Lady's-slipper. W. C. Harris 